\title{
Prenatal Diagnosis of Alobar Holoprosencephaly, Cyclopia, Proboscis, and Isochromosome 18q in the Second Trimester
}

\author{
Meike Bangma, M.D., ${ }^{1}$ Simone Lunshof, M.D., Ph.D., ${ }^{1}$ Diane Van Opstal, Ph.D., ${ }^{2}$ \\ Robert J. Galjaard, M.D., Ph.D., ${ }^{2}$ and Dimitri N.M. Papatsonis, M.D., Ph.D. ${ }^{1}$
}

We would like to present a rare case of alobar holoprosencephaly (HPE) in a fetus diagnosed by routine sonography in the second trimester. Structural sonography demonstrated multiple facial anomalies including absent nasal bone, flat facial profile, hypotelorism, fusion of the orbits and proboscis. After counseling, termination of pregnancy was performed by vaginally administered misoprostol. Karyotyping of amniotic fluid cells revealed an isochromosome $18 \mathrm{q}$, resulting in a trisomy $18 \mathrm{q}$ and monosomy $18 \mathrm{p}$. A stillborn female of $390 \mathrm{~g}$ with several congenital anomalies was born. Postmortem examination demonstrated several anomalies including the HPE, cyclopia, double fused eye, absence of the nose, and the presence of a proboscis. In the literature only a few cases have been published.
\end{abstract}

KEYWORDS: Alobar holoprosencephaly, cyclopia, proboscis, prenatal diagnosis, isochromosome $18 \mathrm{q}$, sonography

We present a case with alobar holoprosencephaly (HPE) and proboscis diagnosed at $21^{+1}$ weeks of gestation during routine sonographic scanning. Chromosome analysis demonstrated an abnormal karyotype $46, \mathrm{XX}, \mathrm{i}(18)$ (q10). Isochromosome $18 \mathrm{q}$ is a rare cytogenetic abnormality. The phenotypical features of this chromosomal abnormality are variable and overlap with trisomy 18 and monosomy $18 \mathrm{p} .{ }^{1} \mathrm{HPE}$ is rarely described in trisomy 18, and occasionally in monosomy $18 \mathrm{p} .{ }^{1}$ Actually, isochromosome 18q associated with alobar HPE was only described eight times before. We give a review of the literature and describe a case of alobar HPE, diagnosed by routine sonography in the second trimester, associated with an isochromosome 18q.

\section{CASE REPORT}

A 37-year-old, gravida 2, para 1 woman was seen for routine sonographic scanning at $20^{+5}$ weeks of gestation. Obstetric history revealed a spontaneous birth of a male fetus of $3080 \mathrm{~g}$ at $40^{+3}$ weeks of gestation. The parents were nonconsanguineous and without dysmorphic features or congenital anomalies. The family history of the mother mentioned a sister who died at the age of 17 because of an intracranial bleeding from an aneurysm. There was no history of infection or drug abuse, and serological screening for HIV, hepatitis B, and syphilis was negative. Until then, the pregnancy had been uneventful. The patient had declined first-trimester aneuploidy screening. At routine sonography, an abnormal

\footnotetext{
${ }^{1}$ Department of Obstetrics and Gynecology, Amphia Hospital Breda, Breda; ${ }^{2}$ Department of Clinical Genetics, Erasmus MC, Rotterdam, The Netherlands.

Address for correspondence and reprint requests: Meike Bangma, Department of Obstetrics and Gynecology, Amphia Hospital Breda, Langendijk 75, 4819 EV, Breda, The Netherlands (e-mail: Mbangma @amphia.nl).
}

Am J Perinatol Rep 2011;1:73-76. Copyright (C) 2011 by Thieme Medical Publishers, Inc., 333 Seventh Avenue, New York, NY 10001, USA. Tel: +1 (212) 584-4662.

Received: February 21, 2011. Accepted after revision: March 28, 2011. Published online: June 8, 2011.

DOI: http://dx.doi.org/10.1055/s-0031-1280850.

ISSN 2157-6998. 

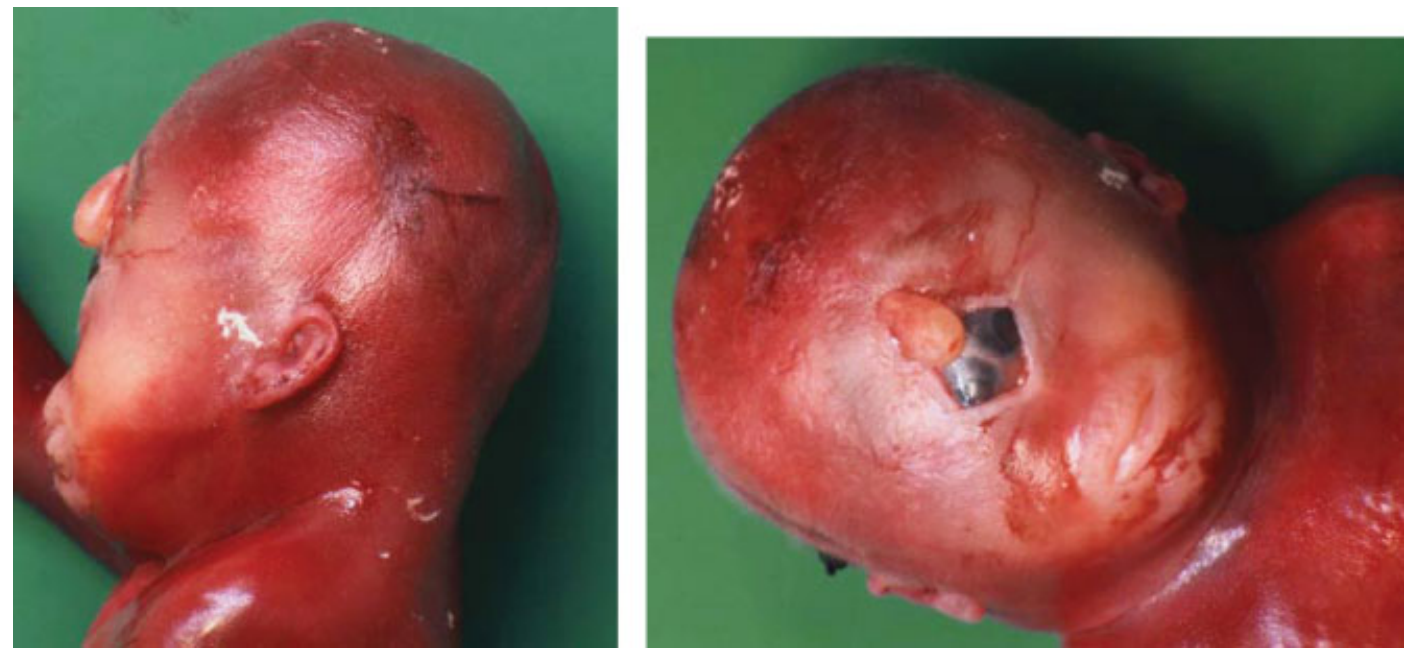

Figure 1 Postnatal image of proboscis and cyclopia with a double fused eye.

image of the fetal brain and facial structures was seen. The patient was referred to our hospital for detailed ultrasound examination. An alobar HPE with facial anomalies including absent nasal bone, flat facial profile, hypotelorism, fusion of the orbits and proboscis were noted. Other anomalies seen were a single umbilical artery, abnormal four-chamber view of the heart, especially abnormal shape of the right atrium, and cystic kidneys. Amniocentesis was

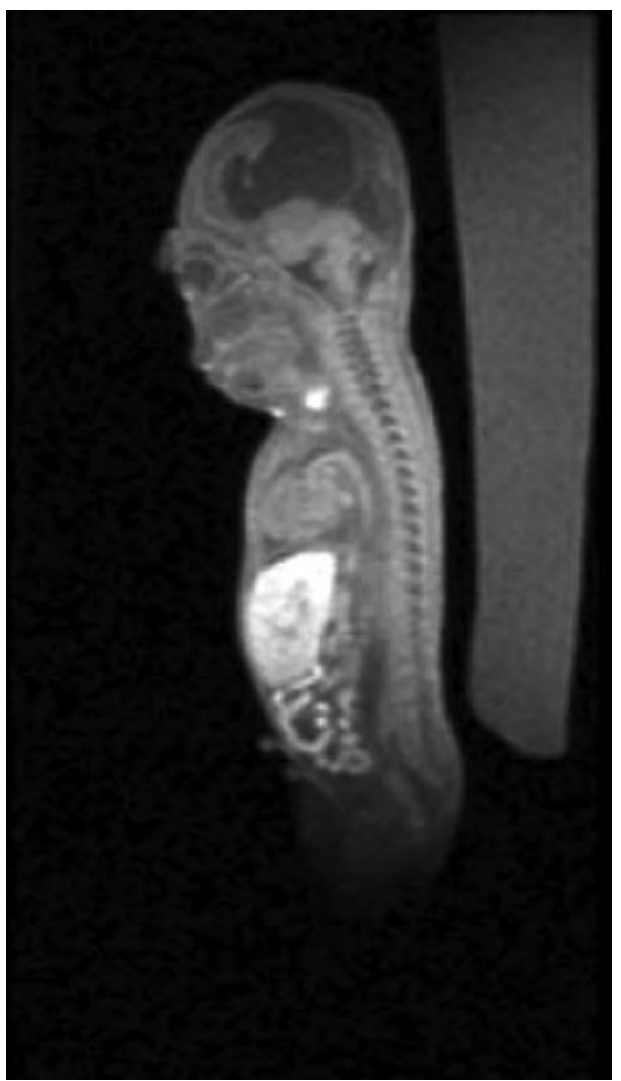

Figure 2 Postmortem magnetic resonance imaging coronal slide demonstrating the monoventricle of the brain of the fetus. performed at $21^{+1}$ weeks of gestation and an abnormal karyotype 46,XX,i(18)(q10) was diagnosed. The fetus therefore had a trisomy of the long arm and a monosomy of the short arm of chromosome 18. The parents decided to terminate the pregnancy on the basis of the ultrasound abnormalities. Eight hours after inducing labor with vaginally administered misoprostol, a stillborn female fetus was delivered at $21^{+3}$ weeks of gestation. Birth weight was $390 \mathrm{~g}$ (normal weight at 21 weeks: $360 \mathrm{~g}$ ). Several congenital anomalies were confirmed at postmortem examination including a cyclopia with a double fused eye, the absence of the nose, and the presence of a proboscis (Fig. 1). Postmortem magnetic resonance imaging scan was performed. The coronal slides gave a definite view of the monoventricular cavity and the proboscis (Fig. 2). Autopsy demonstrated further the alobar HPE (Fig. 3), absence of the corpus callosum, perimembranous ventricular septum defect, bicuspid pulmonal artery valves, malrotation of the small bowel, bilateral hydronephrosis, right megaureter, and uterus bicornis.

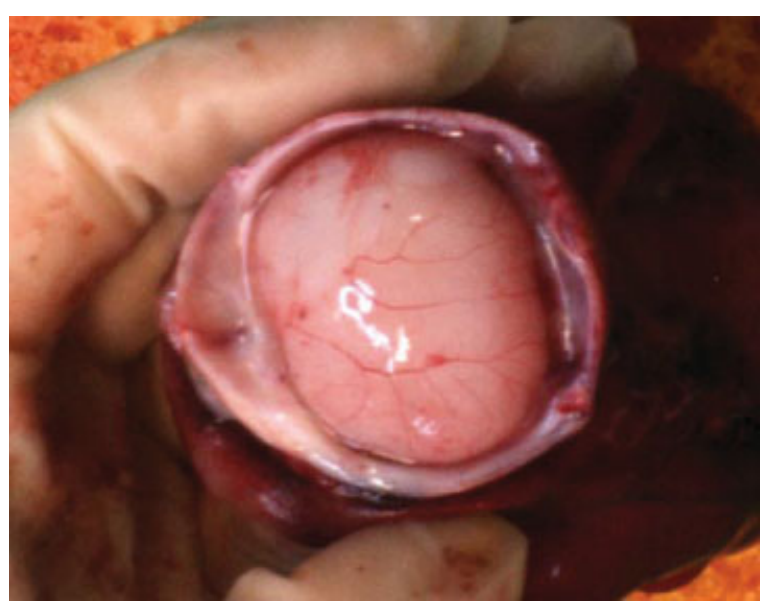

Figure 3 Postmortem image at autopsy demonstrating the monoventricle of the brain. 
Table 1 Cases in the Literature of Isochromosome 18q in Combination with Holoprosencephaly

\begin{tabular}{|c|c|c|c|c|}
\hline Author (Year) & Karyotype & Phenotypes Apart from Holoprosencephaly & $\begin{array}{l}\text { Gravida, } \\
\text { Parity }\end{array}$ & $\begin{array}{l}\text { Maternal } \\
\text { Age (y) }\end{array}$ \\
\hline Wurster-Hill et al $(1991)^{4}$ & $46 X Y i(18 q)$ & $\begin{array}{l}\text { Microcephaly, hypotelorism, hypoplastic nose, } \\
\text { short neck, hypoplasia of radius and ulna, } \\
\text { aplasia of first metacarpals, radial deviation } \\
\text { of the hands, "'rocker bottom' feet }\end{array}$ & $\mathrm{G} 1, \mathrm{P0}$ & 31 \\
\hline Van Essen et al (1993) ${ }^{6}$ & $46 \times X i(18 q)$ & DiGeorge anomaly, streak ovaries & $\mathrm{G} 1, \mathrm{P0}$ & 26 \\
\hline Graf et al $(2002)^{7}$ & $46 X X, i(18)(q 10)$ & $\begin{array}{l}\text { Omphalocele, bilateral hypoplastic forearm } \\
\text { with radial deviation of hands }\end{array}$ & $\mathrm{G} 1, \mathrm{P0}$ & 21 \\
\hline De Pater et al $(1997)^{8}$ & Mosaic 46XX,inv & Hypotelorism, spina bifida & G7, P4 & 27 \\
\hline $\begin{array}{l}\text { Levy-Mozziconacci } \\
\text { et al }(1996)^{9}\end{array}$ & $46 X X,-18,+\operatorname{dic}(18)(p 11,3)$ & $\begin{array}{l}\text { Cyclopia, proboscis, radial deviation of left hand, } \\
\text { agenesis of left thumb, aplasia of right thumb, } \\
\text { bilateral clubfeet, multicystic kidney }\end{array}$ & $\mathrm{G} 1, \mathrm{P0}$ & 27 \\
\hline $\begin{array}{l}\text { Froster-Iskenius } \\
\text { et al }(1984)^{10 *}\end{array}$ & $46 X X, i(18 q)$ & Hypoplastic olfactory bulbs & G5, P2 & 37 \\
\hline Present case (2010) & 46, XX,i(18)(q10) & $\begin{array}{l}\text { Single umbilical artery, cyclopia with double } \\
\text { fused eyes, proboscis, absence of corpus } \\
\text { callosum, perimembranous ventricular septum } \\
\text { defect, bicuspid pulmonal artery valves, } \\
\text { malrotation of small bowel, bilateral } \\
\text { hydronephrosis, right megaureter, } \\
\text { bicornuate uterus }\end{array}$ & G2, P1 & 37 \\
\hline
\end{tabular}

*Froster-Iskenius et al reported a case of isochromosome 18q exhibiting olfactory bulbs as a minor manifestation of holoprosencephaly. ${ }^{10}$

\section{DISCUSSION}

In our case, the fetal karyotyping showed an isochromosome $18 \mathrm{q}$, resulting in a monosomy $18 \mathrm{p}$ and trisomy 18q. This chromosome aberration occurred de novo because both parents had a normal karyotype. The HPE4 gene, TGIF, is located on the distal part of chromosome 18, namely $18 \mathrm{p} 11.31 .^{2}$ Hemizygosity of HPE4 does not automatically result in the phenotype of HPE, suggesting that multiple genetic and environmental factors are involved in the development of the HPE phenotypes. For the de novo case, the recurrence risk for siblings is not significantly increased above that of the general population. ${ }^{3}$

There have only been seven cases ${ }^{4-10}$ previously reported of isochromosome $18 \mathrm{q}$ in combination with HPE (Table 1). Of interest, Levy-Mozziconacci et $\mathrm{al}^{9}$ described a case similar to ours, with a proboscis and a bicornuate uterus, related to $\mathrm{i}(18)(\mathrm{q} 10)$. The karyotype abnormality in that particular case, however, was a $\operatorname{dic}(18)(p 11.3)$, which means the fetus had three copies of the q-arm and three copies of a small part of the p-arm, excluding the locus where HPE4 is located, therefore making their case different from ours.

Abnormalities in the forearms and hand positioning were described in another case ${ }^{11}$ with an isochromosome 18q without HPE, but not in ours. Although the mother in our case is 37 years old, reviewing the other reported cases, it is unlikely that there is an association between isochromosome $18 \mathrm{q}$ and increased maternal age. ${ }^{1}$ This case stresses the importance of standard sonography for all pregnant women between 18 and 21 weeks to detect any congenital anomalies of the fetus.

\section{ACKNOWLEDGMENTS}

The authors thank Dr. D. de Jong, Department of Radiology, for providing the magnetic resonance image.

\section{REFERENCES}

1. Pal S, Siti MI, Ankathil R, Zilfalil BA. Two cases of isochromosome 18q syndrome. Singapore Med J 2007;48: e146-e150

2. Portnoï MF, Gruchy N, Marlin S, et al. Midline defects in deletion 18p syndrome: clinical and molecular characterization of three patients. Clin Dysmorphol 2007;16:247-252

3. Lim AS, Lim TH, Kee SK, et al. Holoprosencephaly: an antenatally-diagnosed case series and subject review. Ann Acad Med Singapore 2008;37:594-597

4. Wurster-Hill DH, Marin-Padilla JM, Moeschler JB, Park JP, McDermet M. Trisomy 18 and $18 \mathrm{p}$ - features in a case of isochromosome $18 \mathrm{q}[46, \mathrm{XY}, \mathrm{i}(18 \mathrm{q})]$ : prenatal diagnosis and autopsy report. Clin Genet 1991;39:142-148

5. Spinner NB, Eunpu DL, Austria JR, Mamunes P. Holoprosencephaly in a newborn girl with 46,XX,i(18q). Am J Med Genet 1991;39:11-12

6. van Essen AJ, Schoots CJ, van Lingen RA, Mourits MJ, Tuerlings JH, Leegte B. Isochromosome $18 \mathrm{q}$ in a girl with holoprosencephaly, DiGeorge anomaly, and streak ovaries. Am J Med Genet 1993;47:85-88 
7. Graf MD, Gill P, Krew M, Schwartz S. Prenatal detection of structural abnormalities of chromosome 18: associations with interphase fluorescence in situ hybridization (FISH) and maternal serum screening. Prenat Diagn 2002;22:645-648

8. de Pater JM, Scheres JM, Brons J. Abnormal chromosome 18 in prenatal diagnosis with holoprosencephaly. Prenat Diagn $1997 ; 17: 887-888$

9. Levy-Mozziconacci A, Piquet C, Scheiner C, et al. i(18q) in amniotic and fetal cells with a normal karyotype in direct chorionic villus sampling: cytogenetics and pathology. Prenat Diagn 1996;16:1156-1159

10. Froster-Iskenius U, Coerdt W, Rehder H, Schwinger E. Isochromosome 18q with karyotype 46,XX,i(18q). Cytogenetics and pathology. Clin Genet 1984;26:549-554

11. Sahoo T, Naeem R, Pham K, et al. A patient with isochromosome $18 \mathrm{q}$, radial-thumb aplasia, thrombocytopenia, and an unbalanced 10;18 chromosome translocation. Am J Med Genet A 2005;133A:93-98 